\title{
Historic Caddo Archaeological Sites in Cherokee County, Texas
}

Timothy K. Perttula

Heritage Research Center, Stephen F. Austin State University

Kevin Stingley

Texas Archeological Stewardship Network, Texas Historical Commission

Mark Walters

Heritage Research Center, Stephen F. Austin State University

Follow this and additional works at: https://scholarworks.sfasu.edu/ita

Part of the American Material Culture Commons, Archaeological Anthropology Commons, Environmental Studies Commons, Other American Studies Commons, Other Arts and Humanities Commons, Other History of Art, Architecture, and Archaeology Commons, and the United States History Commons

Tell us how this article helped you.

This Article is brought to you for free and open access by the Center for Regional Heritage Research at SFA ScholarWorks. It has been accepted for inclusion in Index of Texas Archaeology: Open Access Gray Literature from the Lone Star State by an authorized editor of SFA ScholarWorks. For more information, please contact cdsscholarworks@sfasu.edu. 


\section{Historic Caddo Archaeological Sites in Cherokee County, Texas}

Creative Commons License

(c) (i) (8)

This work is licensed under a Creative Commons Attribution-NonCommercial 4.0 International License 


\title{
Historic Caddo Archaeological Sites in Cherokee County, Texas
}

\author{
Timothy K. Perttula, Kevin Stingley, and Mark Walters
}

\section{Introduction}

The historic archaeology of the Caddo Indian peoples in East Texas has been the subject of considerable interest by Caddo archaeologists for a number of years. Much of that interest has been focused on the investigation of the effects of European contact on Caddo cultural traditions and practices, particularly the impact of introduced European epidemic diseases, and the impact of Spanish, French, and American colonization efforts (cf. Cole 1975; Corbin 1996; Corbin et al. 1990; Fields 2008; Gilmore 1983, 1986; Jackson et al. 2012; Marceaux 2011; Marceaux and Perttula 2010; Marceaux and Wade 2014; Parsons et al. 2002a, 2002b; Perttula 1991, 1992, 1993, 2001, 2002, 2012; Story and Creel 1982).

In recent years, another focus of Historic Caddo archaeological investigations has been on characterizing the material culture record of the different clusters of Caddo Indian sites in East Texas, most notably the study of the diversity in the decorative styles and technologies of their hand-made ceramic vessels as clues to identifying clusters of ethnically and socially related communities in the Angelina and Neches River basins that were living in the region after the mid-17 $7^{\text {th }}$ century A.D. (see Fields 1995; Marceaux 2011; Perttula 2007a, 2007b, 2008; Story 1982, 1995). Herein, we discuss the archaeological findings from four Historic Caddo sites in the Bowles Creek basin in Cherokee County, Texas, that have ceramic assemblages that help to better characterize the nature of what has been defined as Neche cluster sites; "a cluster is strictly a group of possibly related sites in close geographic proximity to each other" (Marceaux 2011:489 and Figure 9.1). Marceaux (2011:499) suggests that certain sites in the middle Neches River basin (and the Bowles Creek valley) are affiliated with the Neche Caddo groups, and the sites described in this article may well belong to the Neche cluster.

\section{Caddo Historic Archaeological Sites in Cherokee County, Texas}

The four historic Caddo archaeological sites discussed in this article are in the Bowles Creek drainage in the middle Neches River basin in Cherokee County, Texas (Figure 1). Bowles Creek flows generally southward to its confluence with the Neches River very near the George C. Davis site (41CE19). All four of the sites were located and recorded by Kevin Stingley of the Cherokee County Historical Commission.

There are two other known historic Caddo sites in this part of the middle Neches River basin, in the aforementioned Neche cluster (Marceaux 2011:499 and Figures 9.1 and 9.7): the Bowles Springs site (41CE48) and the Brooks Lindsey site (41CE293). The Bowles Springs site is on a terrace on the south side of Bowles Creek, and both habitation and mortuary remains have been reported there (Marceaux 2011:193-194), including a substantial grog-tempered and bone-tempered Caddo ceramic sherd assemblage with Patton Engraved fine ware sherds, many sherds with brushing marks, a Perdiz arrow point, as well as two English-style gunflints. The ratio of plain to decorated sherds is a low 0.31 ; the ratio of brushed to plain sherds is 2.43 ; and the ratio of brushed to other wet paste sherds (including sherds with incised or punctated decorative elements) is 6.17 (Marceaux 2011:Tables 6.22 and 6.25). About 28 percent of the sherds at the Bowles Creek site have bone temper inclusions (Marceaux 2011:619). 


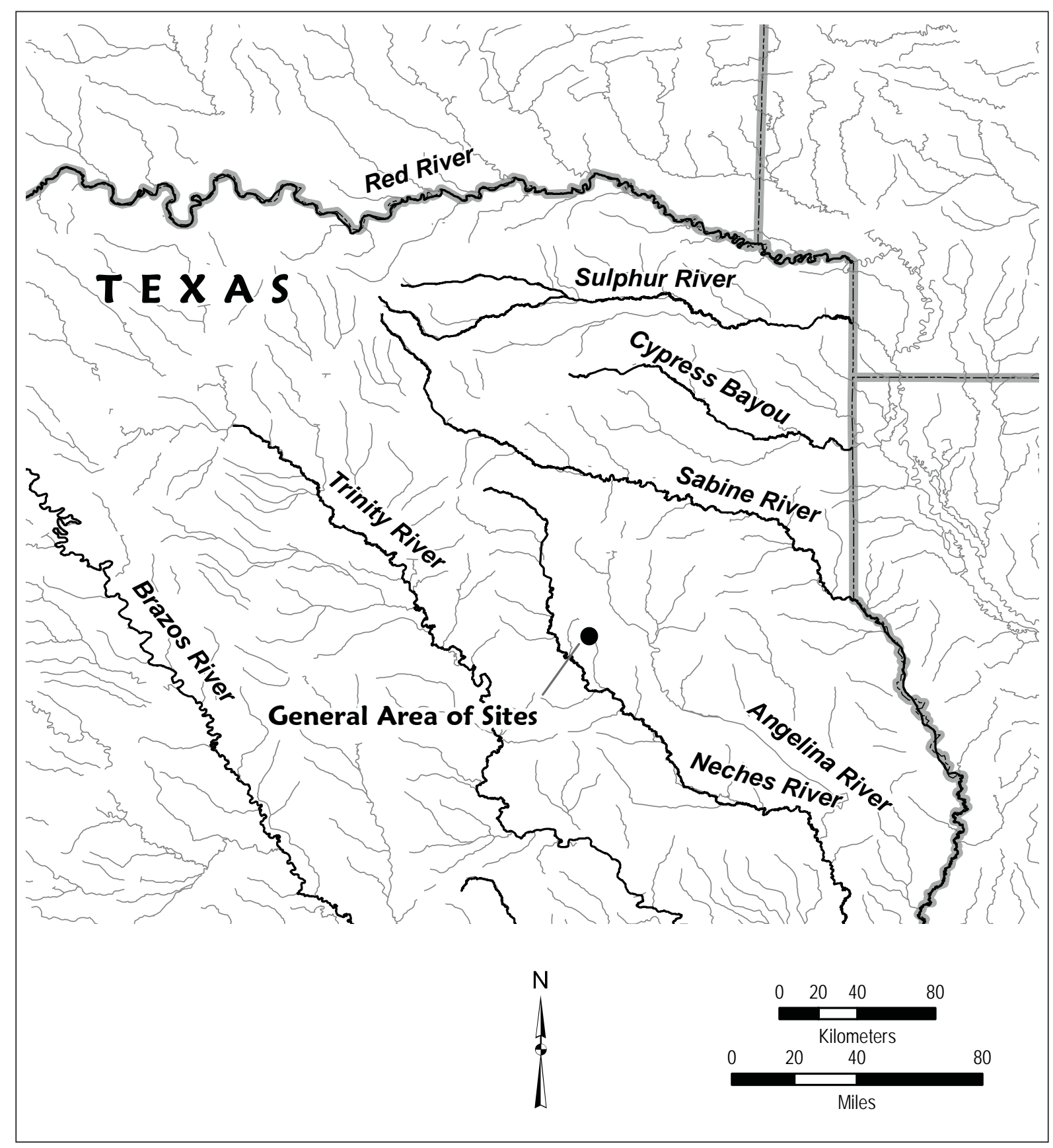

Figure 1. General location of Historic Caddo sites in Cherokee County, Texas, discussed in this article.

The Brooks Lindsey site is also in the Bowles Creek basin, on an alluvial terrace of White Oak Creek near a spring. Collectors reportedly discovered burials at the site as well as a single red and white glass bead (Marceaux 2011:199). One of the more distinctive aspects of the historic Caddo ceramic assemblage, which is almost exclusively grog-tempered (Marceaux 2011:Table 6.28), from the site is the number of Lindsey Grooved utility ware sherds (Marceaux 2011:141,202), the very high proportion of brushed sherds, and there are King Engraved sherds among the fine wares. The plain to decorated sherd ratio is a very low 0.12; the ratio of brushed to plain sherds is 7.50; and the ratio of brushed to other wet paste sherds is 8.65 (Marceaux 2011:Table 6.27). 


\section{Golf Course Site (41CE474)}

This historic Caddo site is on a private golf course in the city limits of Rusk, Texas. It is on an alluvial terrace in the headwaters of a small stream that flows west and southwest in the One Eye and Box creek drainages in the Neches River basin. The landform is wooded, with limited surface visibility, except in gopher mounds and eroded areas. To date, only surface collections have been obtained from the site, and no shovel tests or other excavation units have been conducted here by Stingley.

Caddo ceramic vessel and pipe sherds from the site were sketched and documented in January 2008 during an investigation of Caddo historic archaeological sites in the Neches and Angelina River basins in East Texas (see Marceaux 2011). The majority of those ceramic vessel sherds $(n=21)$ are from Patton Engraved vessels, including one carinated bowl sherd with a horizontal brushed body, but there is at least one Poynor Engraved, var. unspecified carinated bowl sherd, bottle sherds with curvilinear engraved lines, and several sherds from utility ware jars (Figure 2). These include a body sherd with vertical brushing marks on either side of a vertical appliqued fillet and two rim sherds with horizontal brushing marks below a row of tool punctations under the vessel lip.

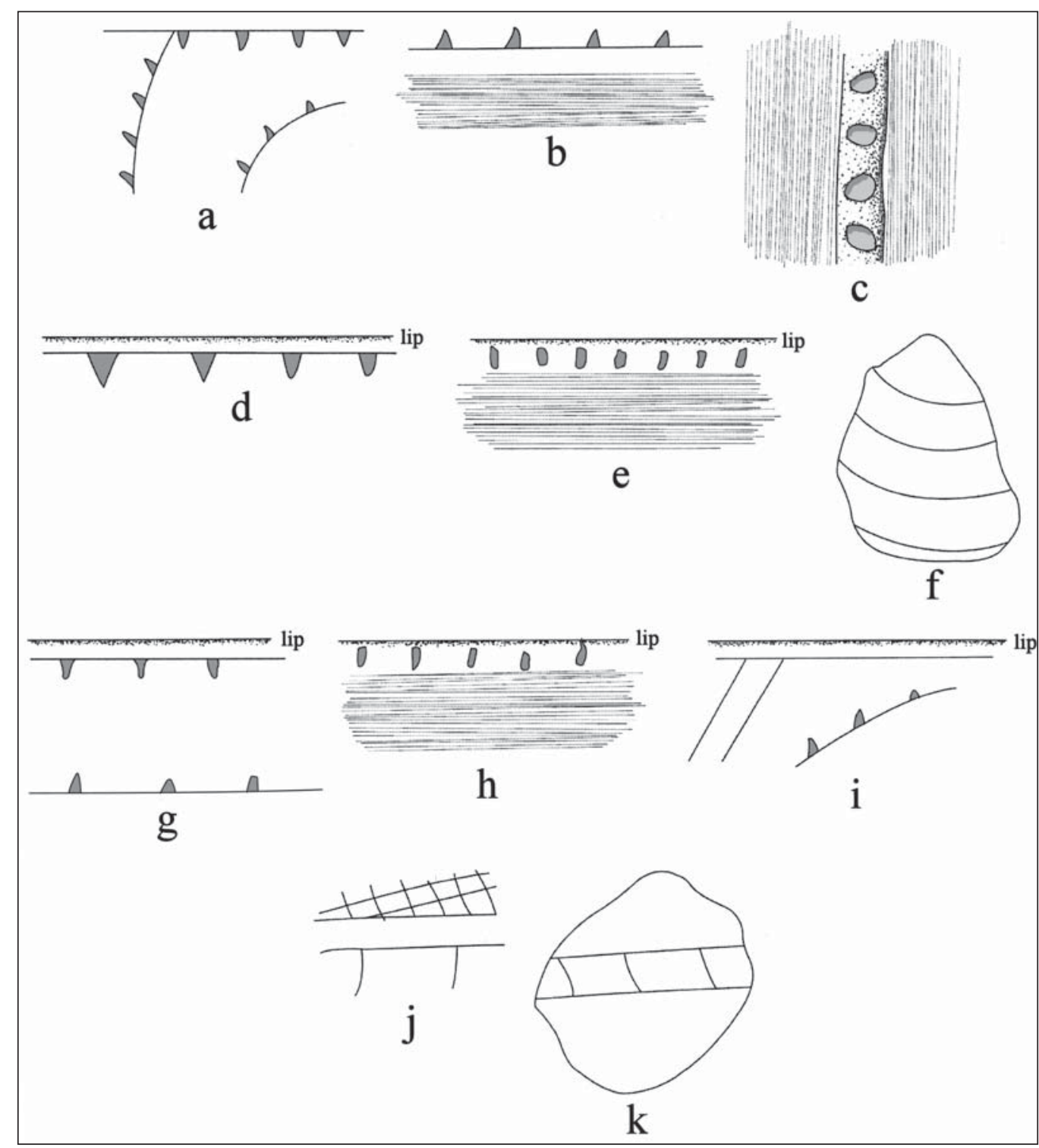

Figure 2. Decorative elements on 2008 sample of sherds from the Golf Course site. 
The five pipe sherds in the studied 2008 collection are from the bowl of two different elbow pipes, specifically what Jackson (1933:75, 1936:Plate 28) refers to as Neches pipes. These pipes have between five and seven rows of small tool punctations on the stem, heel, and bowl (Figure 3).

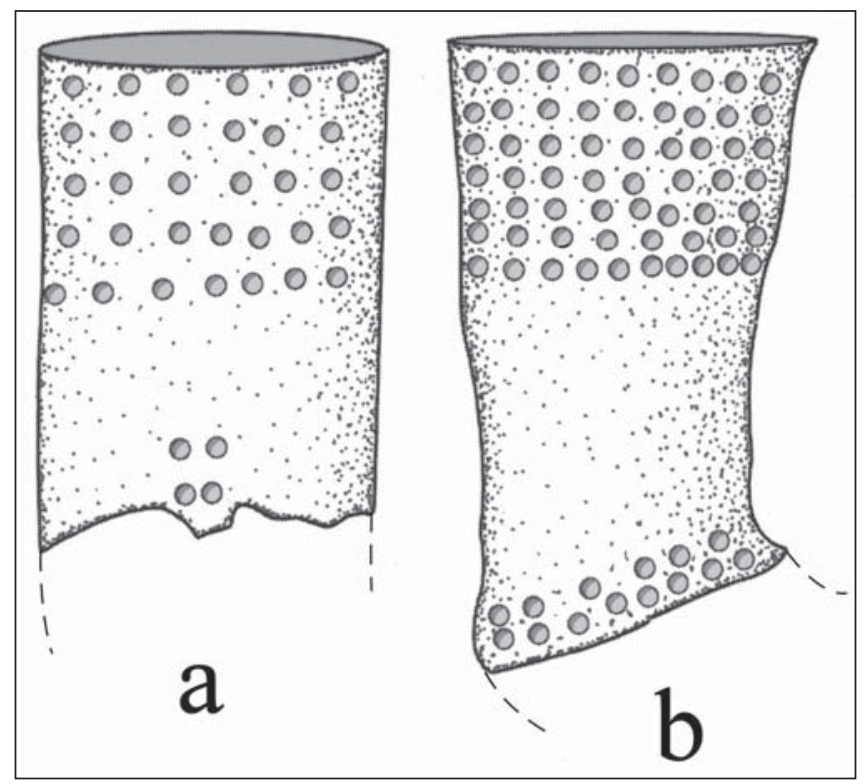

Figure 3. Neches pipe sherds in 2008 sample from the Golf Course site, Cherokee County, Texas.

The more recently recovered collection of artifacts from the GolfCourse site include one celt bit fragment, a side scraper of non-local brownish-gray chert, and 105 plain and decorated ceramic vessel sherds. The celt bit fragment is made from a very dark grayish-brown fine-grained siliceous shale from a southeastern Oklahoma raw material source. The bifacially polished bit is $44.4 \mathrm{~mm}$ wide, $32.5 \mathrm{~mm}$ thick, and at least 36.3 $\mathrm{mm}$ in length.

The majority of the ceramic sherds from the Golf Course site are from utility ware jars (Table 1); these sherds are from vessels decorated with wet paste designs, that is, sherds that are decorated while the vessel was still wet and had not been fired. Less than 25 percent of the sherds are from plain wares or fine ware vessels (i.e., decorated with engraved or trailed lines, or slipped).

Table 1. Ceramic sherd sample from the Golf Course site.

\begin{tabular}{lll}
\hline Ware & No. of sherds & Percentage \\
\hline Plain ware & 24 & 22.9 \\
Utility ware & 79 & 75.2 \\
Fine ware & 2 & 1.9 \\
\hline
\end{tabular}

More than 97 percent of the ceramic sherd sample are from vessels tempered with grog or crushed sherds (Table 2); this includes all of the plain ware and fine ware sherds. Only 3.8 percent of the utility ware sherds - and 2.9 percent of all the sherds - have been tempered with crushed and burned pieces of animal bone. 
Table 2. Temper in the ceramic sherd sample from the Golf Course site.

\begin{tabular}{llll}
\hline Ware & Temper & No. of sherds & Percent \\
\hline Plain & grog & 24 & 100.0 \\
Utility & grog & 76 & 96.2 \\
& bone & 3 & 3.8 \\
Fine & grog & 2 & 100.0 \\
Total grog & & & 97.1 \\
Total bone & & 102 & 2.9 \\
\hline
\end{tabular}

The two fine ware sherds in the present ceramic sherd from the Golf Course site have engraved decorative elements (Table 3). One has parallel engraved lines, and the other is from a Patton Engraved vessel with a row of excised triangular tick marks on a horizontal engraved line (Figure 4).

Table 3. Decorative methods and elements in the ceramic sherd sample from the Golf Course site.

\begin{tabular}{|c|c|c|c|}
\hline Ware & Method & Decorative element & $\mathrm{N}$ \\
\hline \multicolumn{4}{|l|}{ Fine } \\
\hline & Engraved & $\begin{array}{l}\text { horizontal engraved line with } \\
\text { excised triangular tick marks }\end{array}$ & 1 \\
\hline & & parallel engraved lines & 1 \\
\hline \multicolumn{4}{|l|}{ Utility } \\
\hline & Appliqued & parallel appliqued ridges & $3 / 1^{*}$ \\
\hline & Brushed & opposed brushing marks & 7 \\
\hline & & overlapping brushing marks & 2 \\
\hline & & parallel brushing marks & 59 \\
\hline & & vertical brushing marks & 2 \\
\hline & & vertical and diagonal brushing marks & 1 \\
\hline & Brushed-Incised & parallel brushing marks and & 1 \\
\hline & & $\begin{array}{l}\text { overlapping parallel incised lines } \\
\text { parallel brushing marks and overlying } \\
\text { straight and diagonal incised lines }\end{array}$ & 1 \\
\hline & Brushed-Punctated & $\begin{array}{l}\text { diagonal brushing marks and a tool } \\
\text { punctated row }\end{array}$ & 1 \\
\hline & Grooved-Brushed & parallel grooved-parallel brushed & 1 \\
\hline & Incised & diagonal opposed lines & 1 \\
\hline & & straight line & 1 \\
\hline & Punctated & tool punctated row & 1 \\
\hline
\end{tabular}

*three sherds from one vessel 


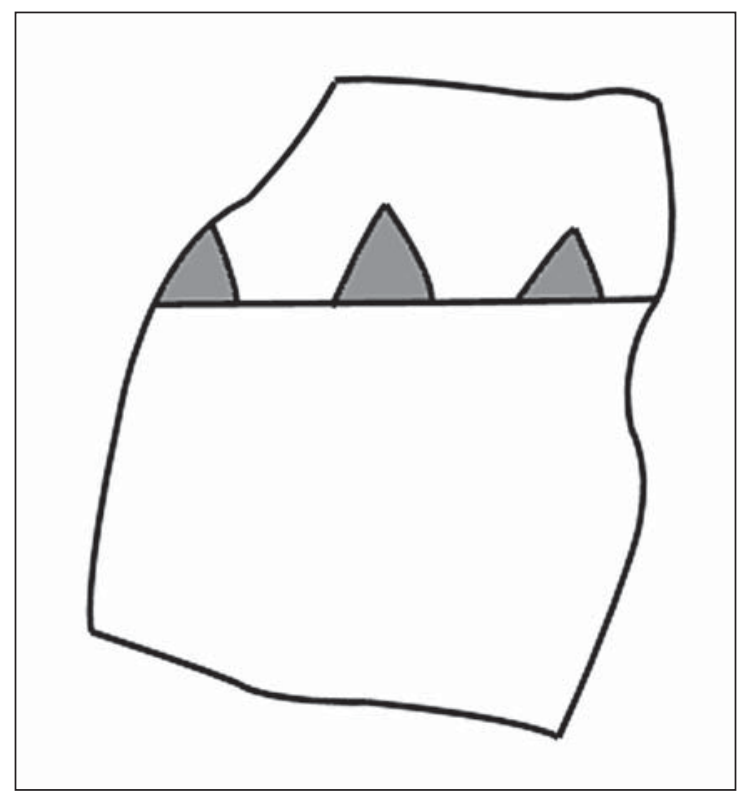

Figure 4. Decorative element on a Patton Engraved body sherd from the Golf Course site.

More than 87 percent of the decorated sherds have brushing marks (see Table 3). Typically these have vertical brushing marks on the rim as well as vertical, opposed, or overlapping brushing marks on the vessel body; these are from Bullard Brushed jars. Three other sherds likely from Bullard Brushed vessels have either brushed-incised or brushed-punctated decorative elements. A Lindsey Grooved body sherd from the site has parallel grooves with parallel brushing marks in the grooves. Sherds with appliqued (1.2 percent of the decorated sherds), incised ( 2.5 percent), and tool punctated (1.2 percent) decorative elements comprise the remainder of the utility wares in the Golf Course site ceramic sherd assemblage.

Several ratios have proved useful in characterizing Historic Caddo ceramic sherd assemblages, and changes in the assemblages both spatially and temporally, in the Angelina and Neches River basins in East Texas (cf. Marceaux 2011), including the ratio of plain to decorated sherds, the ratio of brushed to plain sherds, and the ratio of brushed to other wet paste sherds. In the case of the Golf Course ratio, these ratios indicate a very high proportion of decorated to plain sherds, a very high proportion of sherds from vessels with brushing marks to both plain sherds and sherds from other utility wares decorated with wet paste designs (i.e., appliqued, grooved, incised, neck banded, and punctated) (Table 4). These ratios are comparable to the previously mentioned ceramic assemblages from the Bowles Springs and Brooks Lindsey sites in the Neche cluster in the middle Neches River basin (see discussion below).

Table 4. Ceramic sherd ratios in the ceramic sherd sample from the Golf Course site.

Plain to decorated sherd ratio

Brushed to plain sherds

Brushed to other wet paste sherds
0.30

9.25 


\section{Cornfield Site (41CE476)}

The Cornfield, Peach Orchard, and Bowles Creek sites are situated within a $800 \mathrm{~m}$ area of each other along the northern and western sides of the Bowles Creek valley, between the communities of Alto and Rusk. Based on an examination of other artifact collections and personal communications with landowners, there are several other historic Caddo archaeological sites in this part of the valley that have yet to be documented and recorded.

The Cornfield site is on an upland ridge between Bowles Creek and Turkey Creek, and is known as the 1870s cornfield of an Anglo-American settler of this tract of land. When a 2 acre area of the landform was recently plowed and disked, archaeological evidence of a Caddo settlement was noted on the plowed surface and in gopher mounds. It is now in pasture (Figure 5).

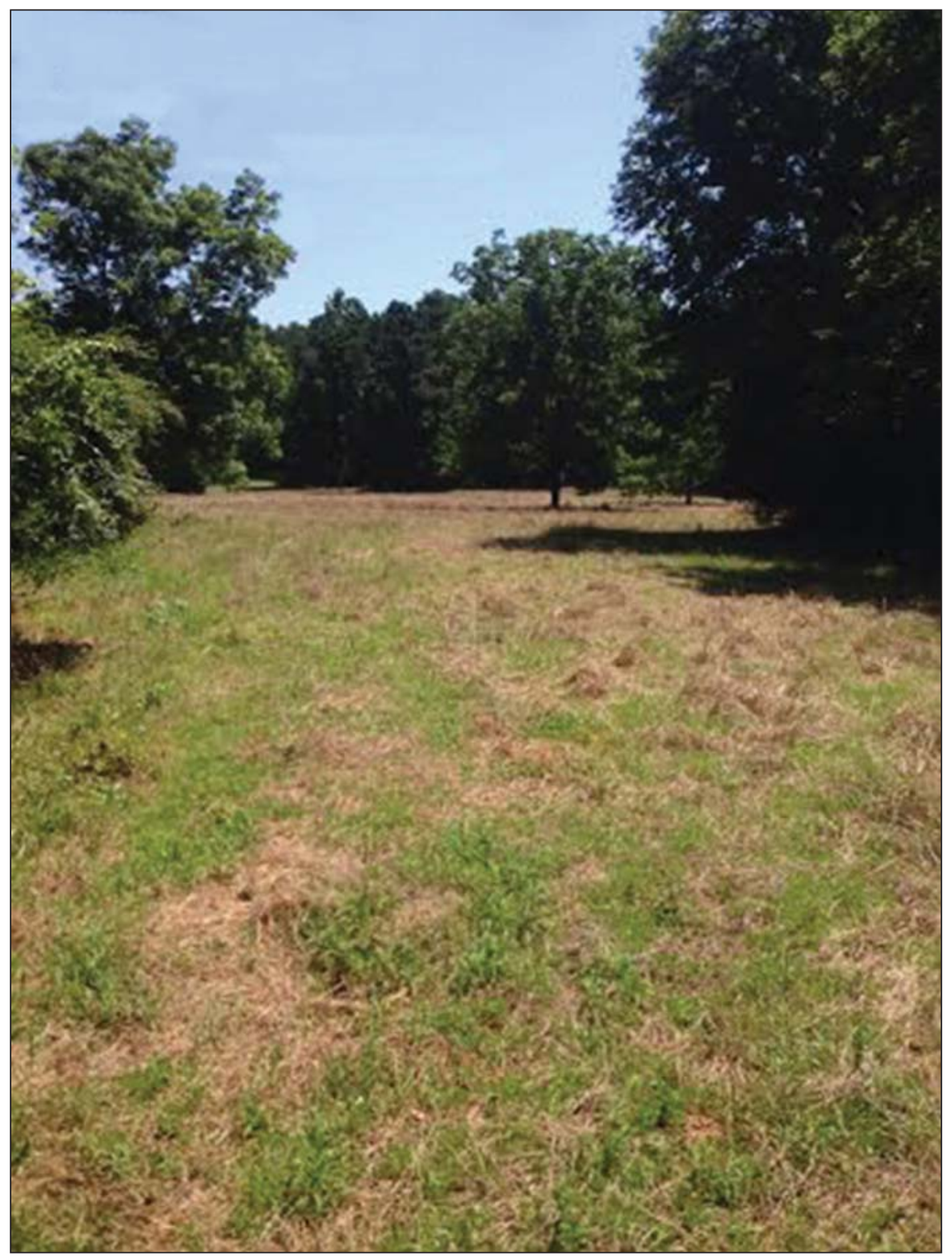

Figure 5. The Cornfield site in Cherokee County, Texas.

There are 227 ceramic sherds in the Cornfield site assemblage. About 62 percent of the sherds are from utility ware jars, and the remainder include sherds from plain and fine wares (Table 5). 
Table 5. Ceramic sherd sample from the Cornfield site.

\begin{tabular}{lll}
\hline Ware & No. of sherds & Percentage \\
\hline Plain ware & 71 & 31.3 \\
Utility ware & 140 & 61.7 \\
Fine ware & 16 & 7.0 \\
\hline
\end{tabular}

About 91 percent of the sherds from the site are from grog-tempered vessels (Table 6), and another 8.8 percent have both either grog and/or burned bone inclusions. The highest proportion of sherds with bone temper - either as the sole temper or in combination with grog — occur in the fine wares (18.8 percent) and plain wares (12.7 percent).

Table 6. Temper in the ceramic sherd sample from the Cornfield site.

\begin{tabular}{llll}
\hline Ware & Temper & No. of sherds & Percent \\
\hline Plain & grog & 62 & 87.3 \\
& bone & 9 & 12.7 \\
Utility & grog & 131 & 93.6 \\
& bone & 9 & 6.4 \\
Fine & grog & 13 & 81.3 \\
& grog-bone & 1 & 6.3 \\
& bone & 2 & 12.5 \\
Total grog & & & \\
Total grog-bone & & 1 & 90.8 \\
Total bone & & 206 & 0.4 \\
\hline
\end{tabular}

The fine ware sherds from the Cornfield site include sherds with both engraved and trailed decorative elements (Table 7); the trailed sherd has a single straight trailed line. Several of the sherds are from Patton Engraved vessels with horizontal or curvilinear engraved lines with excised tick marks (Figure 6f-h). One grog and bone-tempered body sherd from a King Engraved vessel has a rectangular cross-hatched engraved zone (Figure 6c). Other engraved sherds from carinated bowls have diagonal and diagonal opposed lines (Figure 6a-b), and another has an engraved bracket element between parallel lines (Figure 6d). A possible bottle sherd has a curvilinear excised zone on the vessel body (Figure 6e). Finally, one small rim sherd has a narrow horizontal engraved zone under the vessel lip that is filled with a zig-zag line element (Figure 6i).

Table 7. Decorative methods and elements in the ceramic sherd sample from the Cornfield site.

\begin{tabular}{|c|c|c|c|}
\hline Ware & Method & Decorative element & $\mathrm{N}$ \\
\hline \multicolumn{4}{|l|}{ Fine } \\
\hline & Engraved & cross-hatched engraved zone & 2 \\
\hline & & curvilinear engraved line & 1 \\
\hline & & curvilinear excised zone & 1 \\
\hline & & curvilinear line and excised tick marks & 1 \\
\hline & & curvilinear lines and excised tick marks & 1 \\
\hline & & diagonal engraved lines & 1 \\
\hline & & diagonal and opposed engraved lines & 1 \\
\hline & & excised triangular tick marks & 1 \\
\hline & & horizontal lines and bracket el. & 1 \\
\hline
\end{tabular}


Table 7. Decorative methods and elements in the ceramic sherd sample from the Cornfield site, cont.

\begin{tabular}{|c|c|c|c|}
\hline Ware & Method & Decorative element & $\mathrm{N}$ \\
\hline & & $\begin{array}{l}\text { horizontal engraved zone and zig-zag } \\
\text { el. }\end{array}$ & 1 \\
\hline & & parallel lines & 2 \\
\hline & & parallel lines and excised tick marks & 1 \\
\hline & & straight engraved line & 1 \\
\hline & Trailed & straight trailed line & 1 \\
\hline \multicolumn{4}{|c|}{ Utility } \\
\hline & Appliqued & opposed appliqued ridges & 1 \\
\hline & Brushed & horizontal brushing marks & 1 \\
\hline & & opposed brushing marks & 2 \\
\hline & & overlapping brushing marks & 2 \\
\hline & & parallel brushing marks & 115 \\
\hline & & vertical brushing marks & 2 \\
\hline & Brushed-Incised & parallel brushed-incised marks and lines & 2 \\
\hline & & $\begin{array}{l}\text { parallel brushing and overlying parallel } \\
\text { incised lines }\end{array}$ & 1 \\
\hline & Brushed-Punctated & $\begin{array}{l}\text { diagonal brushing marks and tool } \\
\text { punctated row below lip and through } \\
\text { the brushing }\end{array}$ & 1 \\
\hline & Grooved & horizontal grooved & 1 \\
\hline & Incised & diagonal opposed lines & 1 \\
\hline & & parallel incised lines & 2 \\
\hline & & straight line & 8 \\
\hline & Punctated & tool punctated row & 1 \\
\hline
\end{tabular}

Approximately 80.7 percent of all the decorated sherds from the Cornfield site, and 90 percent of the utility ware sherds, have brushing marks on the rim and body of jars (see Table 7), either as the sole decorative element, or in conjunction with incised or punctated elements. There is also one Lindsey Grooved body sherd, a body sherd with diagonal opposed appliqued ridges (Figure 7a), non-descript incised body sherds with parallel or straight lines, as well as one body sherd with diagonal opposed incised lines (Figure 7b). Almost 8 percent of the utility ware sherds have incised elements (see Table 7). There is only one tool punctated sherd in the decorated sherd assemblage from the Cornfield site. 

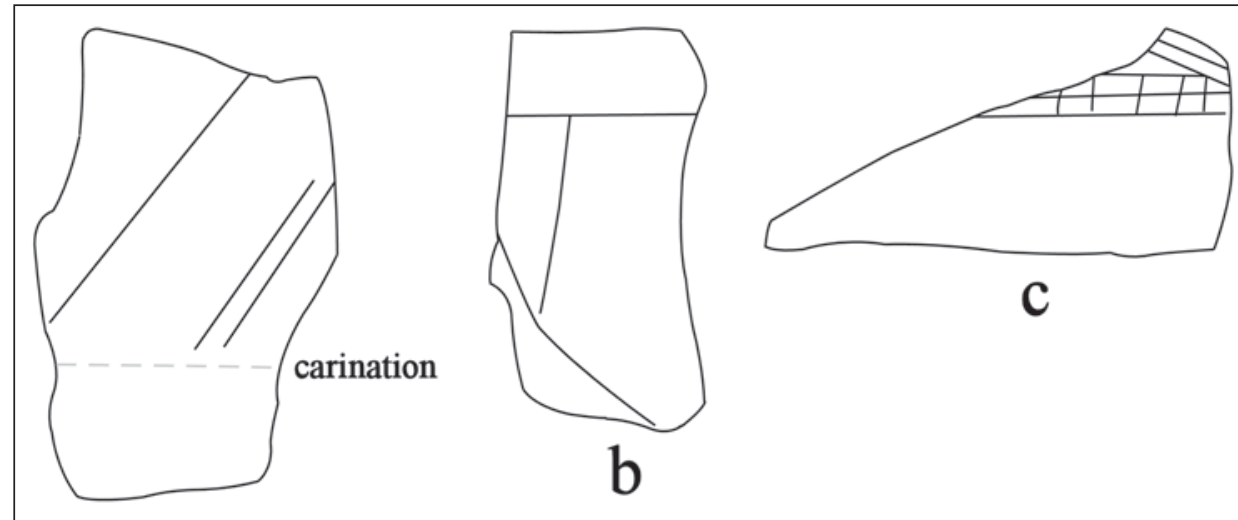

a
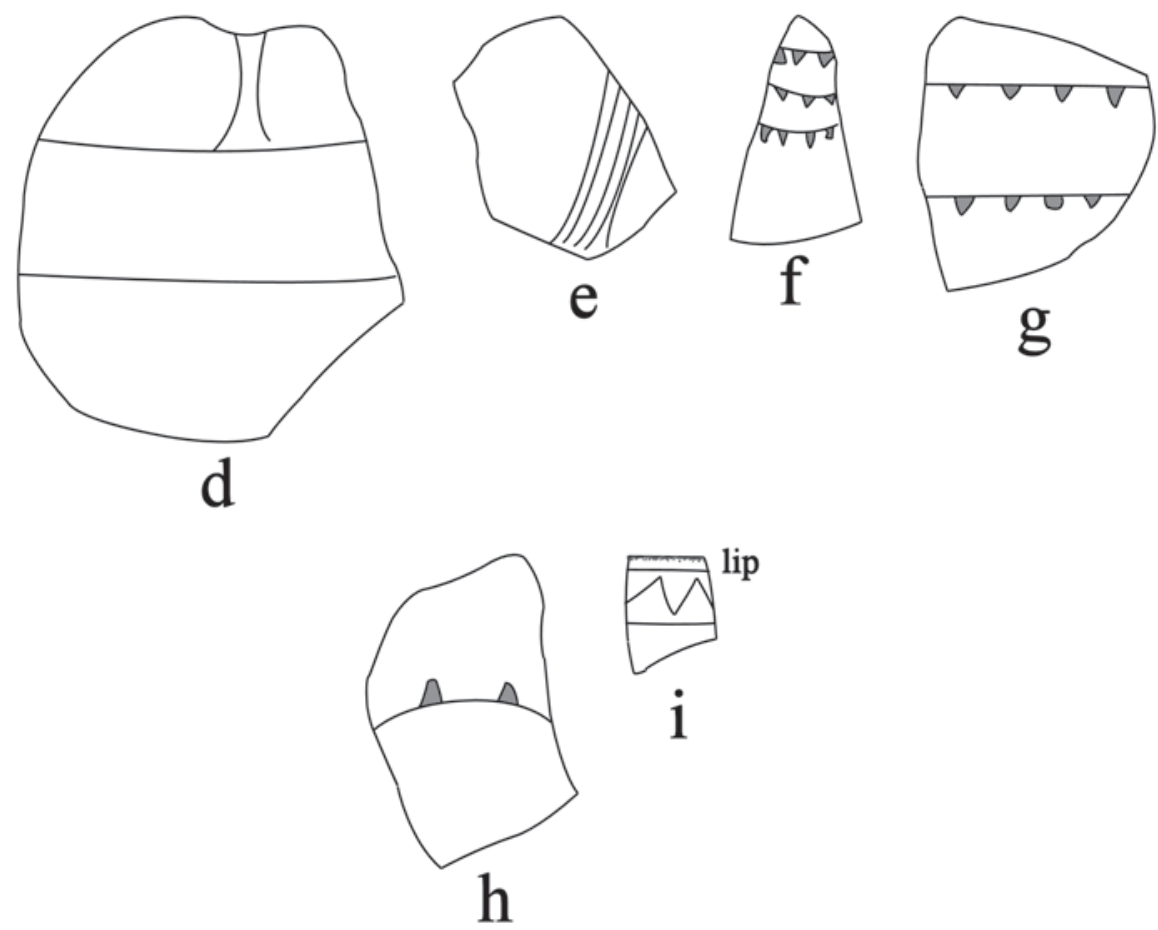

Figure 6. Selected decorative elements in the fine ware sherds from the Cornfield site.

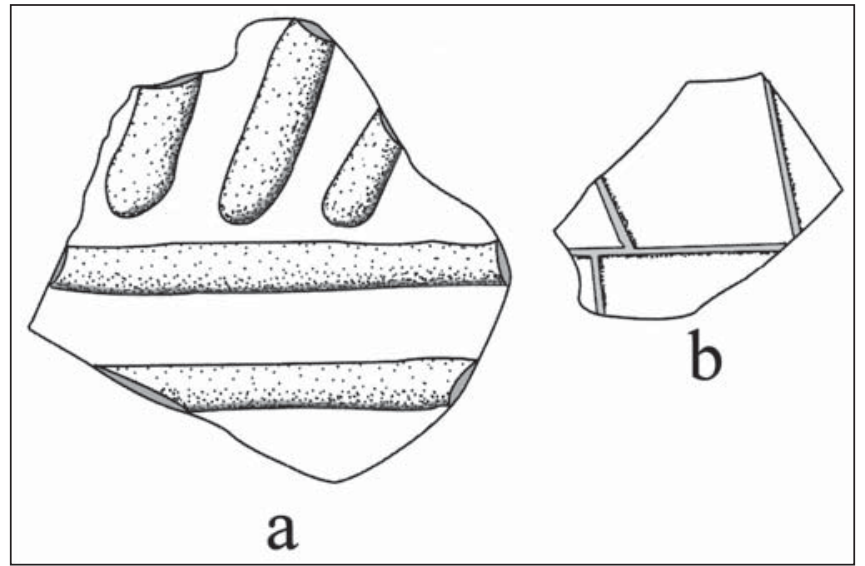

Figure 7. Selected decorative elements in the utility ware sherds from the Cornfield site. 
The sherd ratios for the Cornfield assemblage are indicative of the fact that it has many decorated sherds relative to plain ware sherds, as well as many more brushed sherds than other wet paste sherds (Table 8). Nevertheless, the brushed to plain sherd ratio is only 1.77, suggesting that this assemblage has a higher proportion of plain sherds relative to brushed sherds than does the previously mentioned Bowles Springs site or the Golf Course site (see Table 1).

Table 8. Ceramic sherd ratios in the ceramic sherd sample from the Cornfield site.

\begin{tabular}{lc}
\hline Plain to decorated sherd ratio & 0.45 \\
Brushed to plain sherds & 1.77 \\
Brushed to other wet paste sherds & 7.0 \\
\hline
\end{tabular}

\section{Peach Orchard Site (41CE477)}

The Peach Orchard site is also in the Bowles Creek valley, and it has been exposed in erosion along a county road that bisects the southern end of the upland landform. The remainder of the landform is primarily grass-covered (Figure 8).

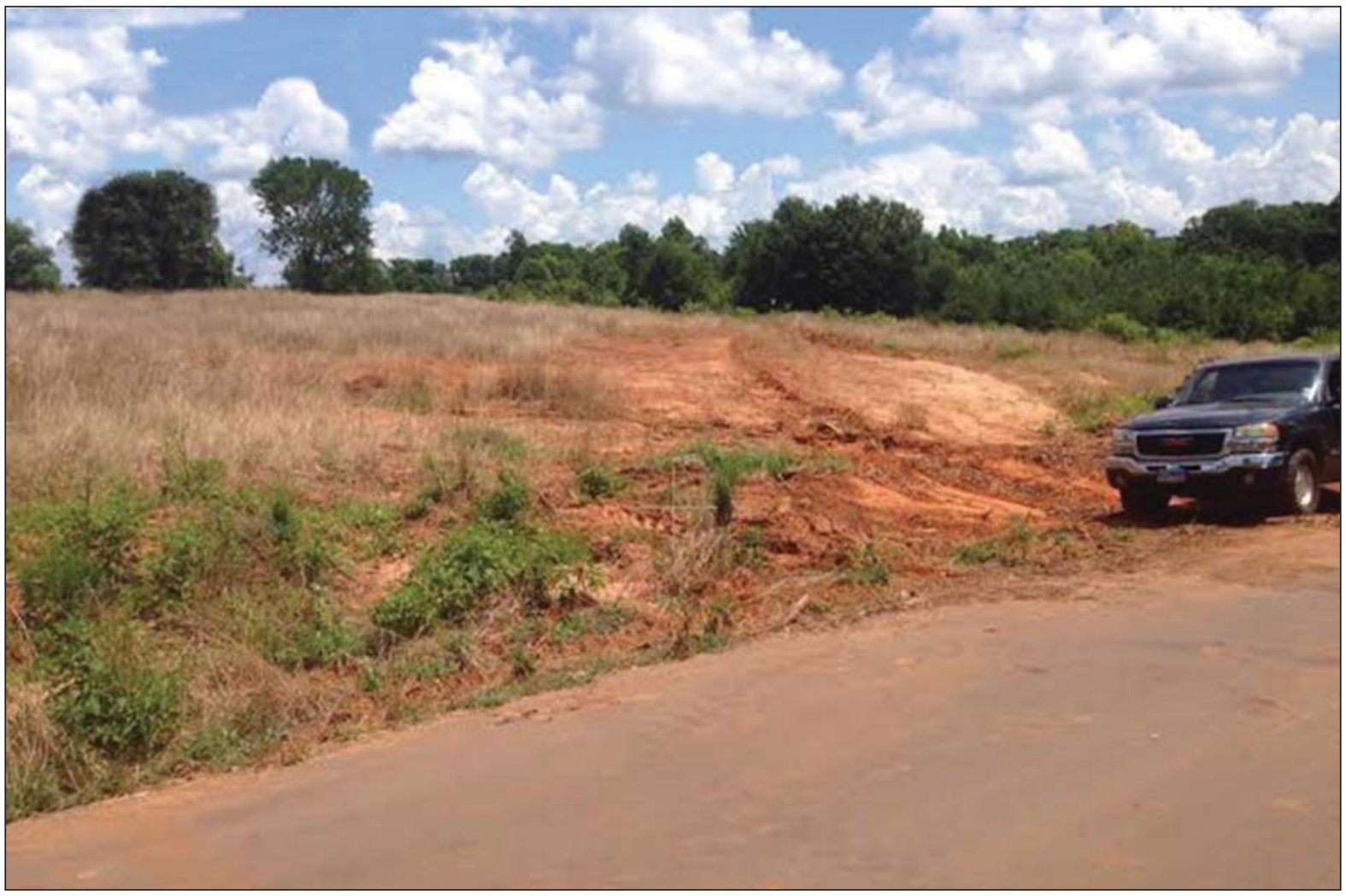

Figure 8. Looking northeast at the Peach Orchard site in Cherokee County, Texas.

At present, surface collections at the Peach Orchard site have obtained 71 ceramic sherds, mostly from utility ware jars (Table 9). Sherds from plain ware and fine ware vessels only comprise 22.5 percent of the assemblage. 
Table 9. Ceramic sherd sample from the Peach Orchard site.

\begin{tabular}{lll}
\hline Ware & No. of sherds & Percentage \\
\hline Plain ware & 11 & 15.5 \\
Utility ware & 55 & 77.5 \\
Fine ware & 5 & 7.0 \\
\hline Totals & 71 & 100.0 \\
\hline
\end{tabular}

The small ceramic sherd assemblage from the site is almost entirely from grog-tempered vessels (Table $10)$, especially including the utility wares. The few bone-tempered sherds were most common in the plain wares $(9.1$ percent) and the fine wares (20.0 percent).

Table 10. Temper in the ceramic sherd sample from the Peach Orchard site.

\begin{tabular}{llll}
\hline Ware & Temper & No. of sherds & Percent \\
\hline Plain & grog & 10 & 90.0 \\
& bone & 1 & 9.1 \\
Utility & grog & 54 & 98.2 \\
& bone & 1 & 1.8 \\
Fine & grog & 4 & 80.0 \\
& bone & 1 & 20.0 \\
Total grog & & 68 & 95.8 \\
Total bone & & 3 & 4.2 \\
\hline
\end{tabular}

Two of the fine ware sherds are from Patton Engraved vessels with either excised triangular or linear tick marks (Table 11 and Figure 9). The other fine wares have simple opposed or straight line elements.

Table 11. Decorative methods and elements in the ceramic sherd sample from the Peach Orchard site.

\begin{tabular}{lll}
\hline Ware & Method & Decorative element \\
\hline Fine & & \\
& Engraved & curvilinear engraved lines with excised triangular tick marks \\
& linear tick marks \\
& opposed engraved lines \\
& straight engraved line
\end{tabular}

Utility

$\begin{array}{ll}\text { Brushed } & \begin{array}{l}\text { horizontal brushing marks } \\ \text { opposed brushing marks } \\ \text { overlapping brushing marks } \\ \text { parallel brushing marks }\end{array} \\ \text { Brushed-Punctated } & \begin{array}{l}\text { horizontal brushing marks and tool } \\ \text { punctated row below lip and through the brushing }\end{array} \\ \text { Grooved } & \text { horizontal grooved } \\ \text { Incised } & \text { parallel incised lines }\end{array}$

2 
Table 11. Decorative methods and elements in the ceramic sherd sample from the Peach Orchard site, cont.

\begin{tabular}{llll}
\hline Ware & Method & Decorative element & $\mathrm{N}$ \\
\hline Incised-Punctated & $\begin{array}{l}\text { tool punctated row below the lip } \\
\text { and above horizontal incised line }\end{array}$ & 1 \\
\hline
\end{tabular}

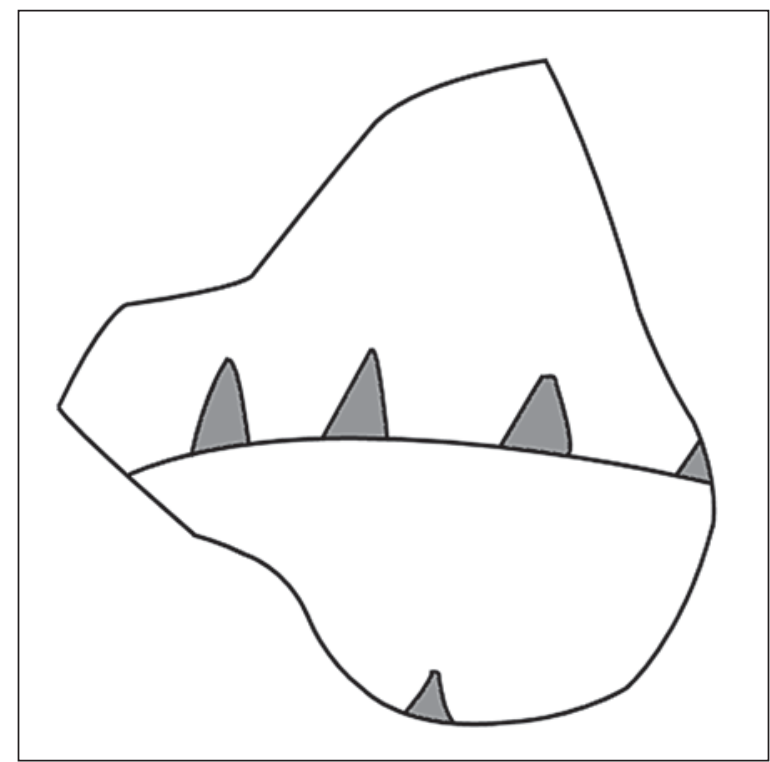

Figure 9. Decorative elements on a Patton Engraved body sherd from the Peach Orchard site.

More than 94 percent of the utility ware sherds from the site have brushed decorative elements, including horizontal brushing marks on the rim of utility ware jars and opposed, overlapping, and vertical brushing marks on the vessel body (see Table 11). One rim has a row of tool punctations below the vessel lip that had been pushed through the brushing. One of the utility ware sherds is from a Lindsey Grooved vessel, and two others have either incised or incised-punctated decorative elements (see Table 11).

The Peach Orchard site has a very low plain to decorated sherd ratio, and many brushed sherds compared to plain ware sherds (Table 12). There also are not many other wet paste sherds in the ceramic assemblage from the site compared to sherds from brushed vessels, based on the brushed to other wet paste sherd ratio of 13.0.

Table 12. Ceramic sherd ratios in the ceramic sherd sample from the Peach Orchard site.

Plain to decorated sherd ratio

Brushed to plain sherds

Brushed to other wet paste sherds
0.18

13.0

Finally, there is one blue shell-edged whiteware rim sherd in the collection from the site. It has an even or regular scalloped rim with straight impressed lines (Figure 10); such vessels were produced between ca. 1800 and 1840 (Hunter and Miller 2009:13), suggesting it may be associated with an early $19^{\text {th }}$ century occupation of the site, either by a Caddo Indian group, or an early Anglo-American settler. 


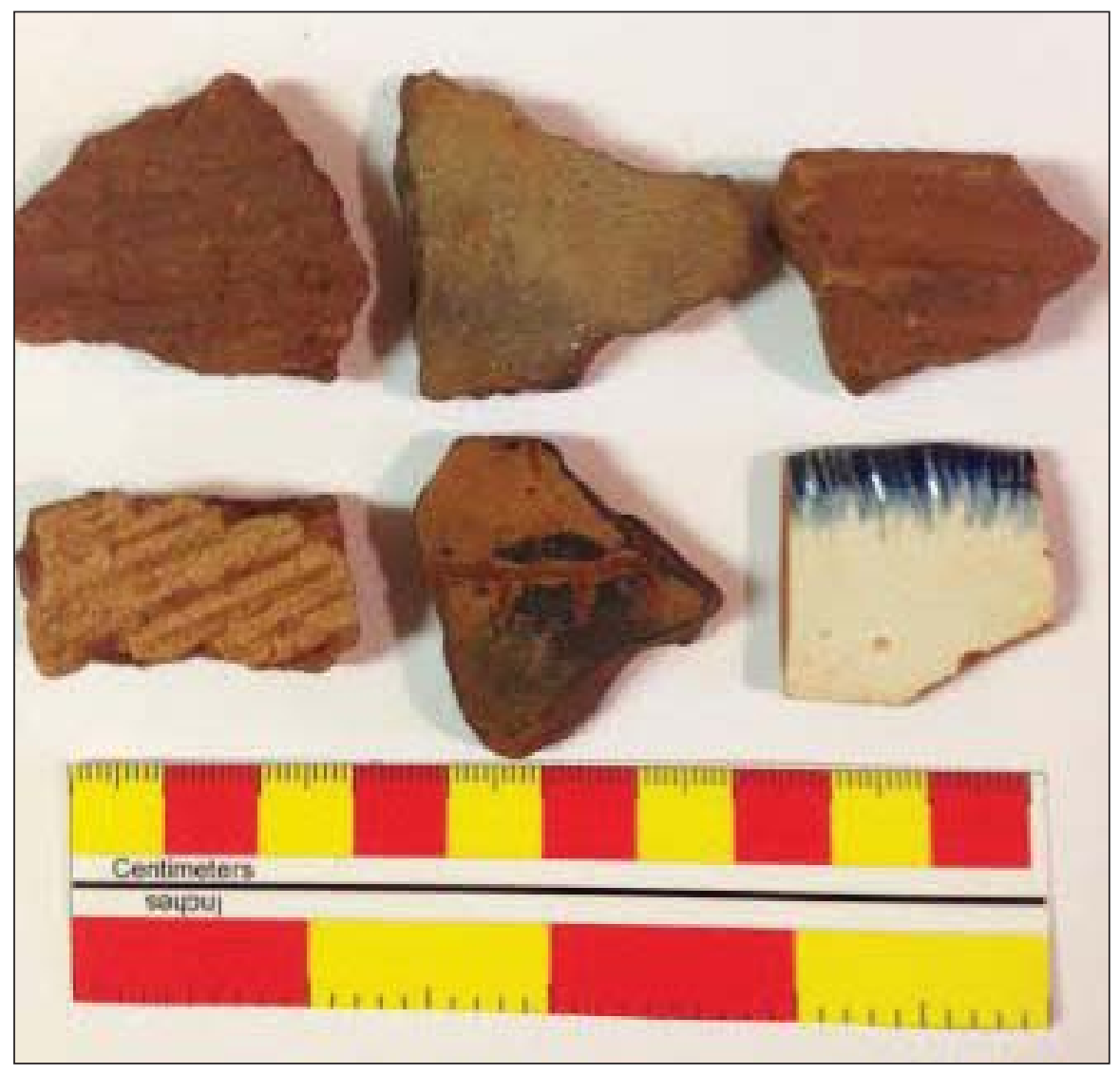

Figure 10. Selected ceramic sherds from the Peach Orchard site, including a blue shell-edged rim sherd.

\section{Bowles Creek Site (41CE475)}

The Bowles Creek site is located on a low alluvial rise in a pasture ca. $20 \mathrm{~m}$ north of Bowles Creek. It was located during a surface walk over, when Caddo ceramic sherds were noted in a number of gopher mounds. A number of shovel tests ( $\mathrm{n}=13$, generally $35-40 \times 55-60 \mathrm{~cm}$ in width and length and $30-50 \mathrm{~cm}$ in depth) and three units (generally $1 \times 1 \mathrm{~m}$ in size) have been excavated by Stingley at the site (Figure 11); the units were excavated to between $50-80 \mathrm{~cm}$ bs. Animal bones $(\mathrm{n}=35)$, both burned and unburned, charred plant remains (wood charcoal, $n=15+)$, and a few pieces of burned clay $(n=10)$ and fire-cracked rock $(n=2)$ were recovered from the archaeological deposits in ST 1, ST 2, Unit 1, Unit 2, and Unit 3. The increase in the density of ceramic sherds, animal bone, and burned clay pieces in Unit 3 below $60 \mathrm{~cm}$ bs suggests that a cultural pit feature (perhaps an earth oven or cooking feature) was encountered in the excavations there. The site covers at least an estimated $55 \mathrm{~m}$ (east-west) x $20 \mathrm{~m}$ (north-south) area (Figure 12).

The archaeological investigations at the Bowles Creek site have recovered 617 ceramic sherds from gopher mounds, shovel tests, and excavation units (Table 13). Almost 69 percent of the sherds are from utility ware jars. The density of sherds in the shovel tests ranges from as little as seven sherds (ST 6) to 38 sherds (in ST 2). In the units, sherd densities are substantial: Unit $1(n=94)$, Unit $2(n=42)$, and Unit $3(n=218)$. 


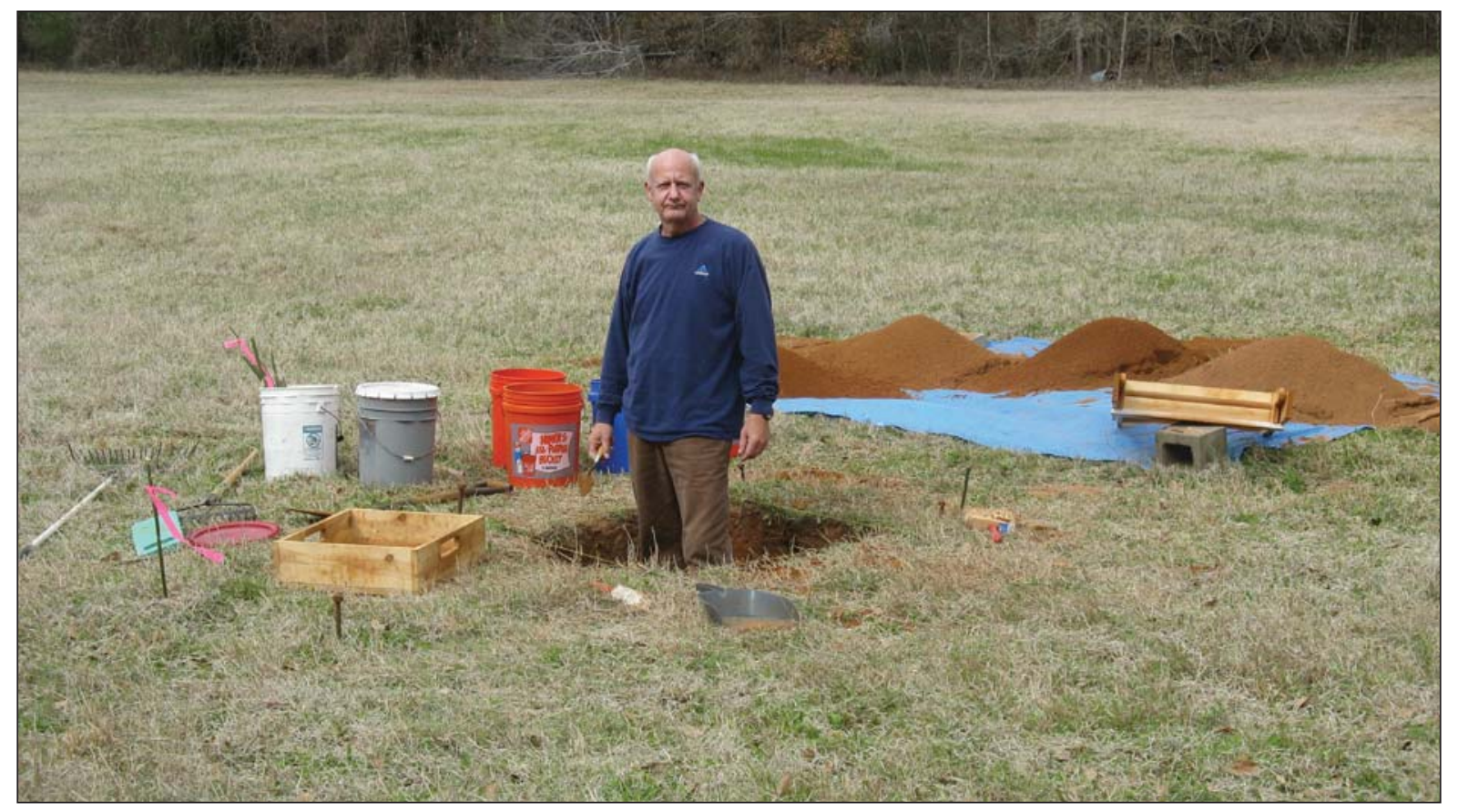

Figure 11. Unit 2 excavations by Kevin Stingley at the Bowles Creek site.

Table 13. Ceramic sherd sample from the Bowles Creek site.

\begin{tabular}{lll}
\hline Ware & No. of sherds & Percentage \\
\hline Plain ware & 156 & 25.3 \\
Utility ware & 424 & 68.7 \\
Fine ware & 37 & 6.0 \\
\hline
\end{tabular}

About 91 percent of the sherds from the site are from grog-tempered vessels, including sherds from vessels tempered with both grog and bone (Table 14). Approximately 10 percent of the sherds are from bonetempered vessels. The highest proportion of bone-tempered sherds are in the plain wares ( 9.0 percent) and the utility wares (10.9 percent), particularly in vessels with brushed decorative elements. Only 2.7 percent of the sherds from fine ware vessels are bone-tempered.

Table 14. Temper in the ceramic sherd sample from the Bowles Creek site.

\begin{tabular}{llll}
\hline Ware & Temper & No. of sherds & Percent \\
\hline Plain & grog & 142 & 91.0 \\
& bone & 14 & 9.0 \\
Utility & grog & 378 & 89.1 \\
& grog-bone & 4 & 0.9 \\
Fine & bone & 42 & 10.0 \\
& grog & 36 & 97.3 \\
& bone & 1 & 2.7 \\
Total grog & & & \\
Total grog-bone & & 456 & 90.1 \\
Total bone & & 57 & 0.6 \\
\hline
\end{tabular}




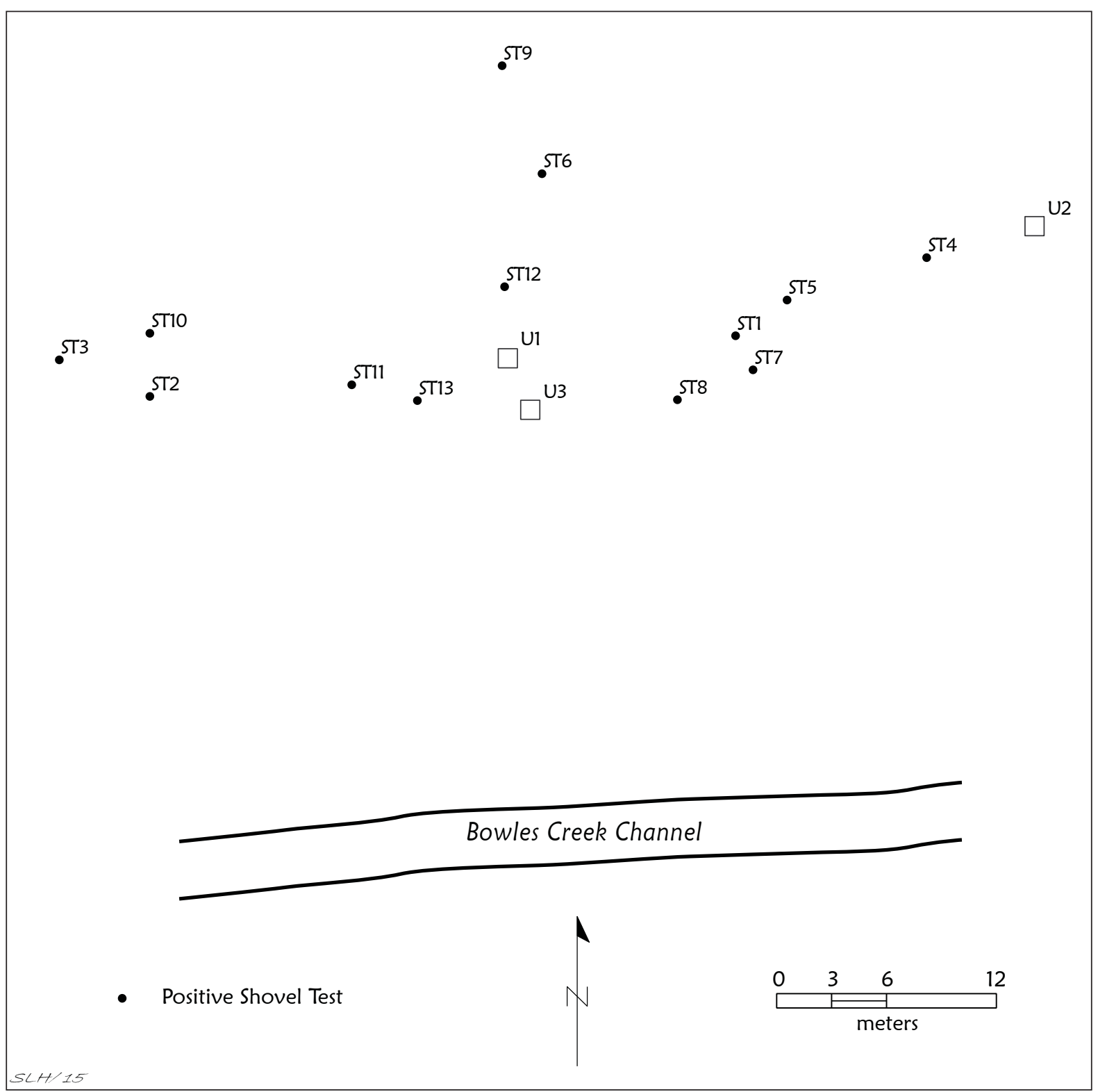

Figure 12. Map of the Bowles Creek site showing the location of shovel tests and hand-excavated units.

The fine ware sherds have a variety of engraved decorative elements ( 7.2 percent of all the decorated sherds) (Table 15), engraved-brushed (0.2 percent, Figure 13c, Poynor Engraved), engraved-punctated (0.4 percent, Figure 13d, Patton Engraved), and trailed (0.4 percent), likely from Keno Trailed vessels. Sherds from both Patton Engraved (Figure 13d, f) and Poynor Engraved (Figure 13c, g, j) vessels are present in the Bowles Creek site fine wares; the Patton Engraved sherds have both linear and excised triangular tick marks (Table 15). One possible Poynor Engraved rim sherd has a row of tool punctates on the folded out rim, along with horizontal and vertical engraved lines that end in a triangular element (Figure 13e). Other fine ware engraved sherds have simple geometric elements, with horizontal-diagonal (Figure 13a) and horizontal-vertical (Figure 13b, h-i) decorative elements. 
Table 15. Decorative methods and elements in the ceramic sherd sample from the Bowles Creek site.

\begin{tabular}{|c|c|c|c|}
\hline Ware & Method & Decorative element & $\mathrm{N}$ \\
\hline Fine & Engraved & $\begin{array}{l}\text { horizontal engraved line } \\
\text { horizontal engraved line and overlying } \\
\text { line with linear tick marks } \\
\text { horizontal-diagonal engraved lines } \\
\text { horizontal-diagonal lines, one with excised tick marks } \\
\text { horizontal and diagonal opposed lines } \\
\text { horizontal-vertical engraved lines } \\
\text { horizontal-vertical lines and curvilinear } \\
\text { hatched triangle el. } \\
\text { horizontal-vertical-diagonal lines } \\
\text { linear excised zone } \\
\text { linear tick marked row } \\
\text { parallel engraved lines } \\
\text { parallel-diagonal engraved lines } \\
\text { parallel engraved lines with excised } \\
\text { triangular tick marks } \\
\text { straight engraved line }\end{array}$ & $\begin{array}{l}1 \\
1 \\
1 \\
4 \\
1 \\
1\end{array}$ \\
\hline & Engraved-Brushed & $\begin{array}{l}\text { horizontal and vertical engraved lines } \\
\text { and horizontal brushing marks on body }\end{array}$ & 1 \\
\hline & $\begin{array}{l}\text { Engraved- } \\
\text { Punctated }\end{array}$ & $\begin{array}{l}\text { tool punctated row below the lip and } \\
\text { horizontal engraved line with linear tick marks } \\
\text { tool punctated row at lip and horizontal- } \\
\text { vertical engraved lines }\end{array}$ & 1 \\
\hline & Trailed & $\begin{array}{l}\text { curvilinear trailed lines } \\
\text { horizontal trailed lines }\end{array}$ & $\begin{array}{l}1 \\
1\end{array}$ \\
\hline
\end{tabular}

Utility

Brushed

diagonal brushing marks

diagonal and overlapping brushing marks

horizontal brushing marks 5

opposed brushing marks $\quad 7$

overlapping brushing marks $\quad 4$

parallel brushing marks 366

vertical brushing marks $\quad 4$

Brushed-Incised $\quad$ parallel brushed-incised marks and lines 1

parallel brushing marks and overlying $\quad 1$

opposed parallel incised lines

parallel brushing and overlying $\quad 1$

opposed straight incised line

parallel brushing and overlying $\quad 1$

parallel incised lines 
Table 15. Decorative methods and elements in the ceramic sherd sample from the Bowles Creek site, cont.

\begin{tabular}{|c|c|c|c|}
\hline Ware & Method & Decorative element & $\mathrm{N}$ \\
\hline & Brushed-Punctated & $\begin{array}{l}\text { parallel brushed and tool punctated } \\
\text { row through the brushing }\end{array}$ & 2 \\
\hline & Grooved & parallel grooved & 1 \\
\hline & \multirow[t]{4}{*}{ Incised } & diagonal opposed incised lines & 1 \\
\hline & & parallel incised lines & 7 \\
\hline & & parallel and diagonal incised lines & 1 \\
\hline & & straight incised line & 4 \\
\hline & Pinched & parallel pinched ridges & 3 \\
\hline & \multirow[t]{6}{*}{ Punctated } & circular punctated rows & 2 \\
\hline & & single fingernail punctate & 1 \\
\hline & & fingernail punctated row below the lip & 1 \\
\hline & & tool punctated row below the lip & 2 \\
\hline & & tool punctated rows & 3 \\
\hline & & single tool punctate & 1 \\
\hline
\end{tabular}

Sherds with brushed decorative elements comprise 84.8 percent of the decorated sherds from the Bowles Creek site (see Table 15); these are likely from Bullard Brushed jars. They have diagonal, horizontal, or vertical brushing marks on the rim, and opposed, overlapping, or vertical brushing marks on the vessel body. Another 1.3 percent of the sherds have either brushed-incised or brushed-punctated decorative elements (see Table 15). At least two of the sherds are from Spradley Brushed-Incised vessels that have parallel brushed vessel surfaces that are overlain with opposed parallel incised lines. About 0.6 percent of the decorated sherds are from Killough Pinched vessels with parallel pinched ridges on vessel bodies. One decorated sherd $(0.2$ percent) is from a Lindsey Grooved vessel. The remaining utility ware sherds have simple geometric incised elements (2.8 percent of the decorated sherds), or circular ( 0.4 percent), fingernail ( 0.4 percent), or tool punctated (1.3 percent) decorative elements (see Table 15).

The ceramic sherd assemblage metric ratios for the Bowles Creek site assemblage is provided in Table 16. Like other ceramic sherd assemblages in the Bowles Creek basin, the Bowles Creek site assemblage has a low plain to decorated sherd ratio, a relatively high proportion of brushed to plain sherds, and a considerable number of brushed sherds in the utility wares relative to the sherds from other wet paste-decorated vessels.

Table 16. Ceramic sherd ratios in the ceramic sherd sample from the Bowles Creek site.

$\begin{array}{ll}\text { Plain to decorated sherd ratio } & 0.34\end{array}$

Brushed to plain sherds

Brushed to other wet paste sherds

11.3 


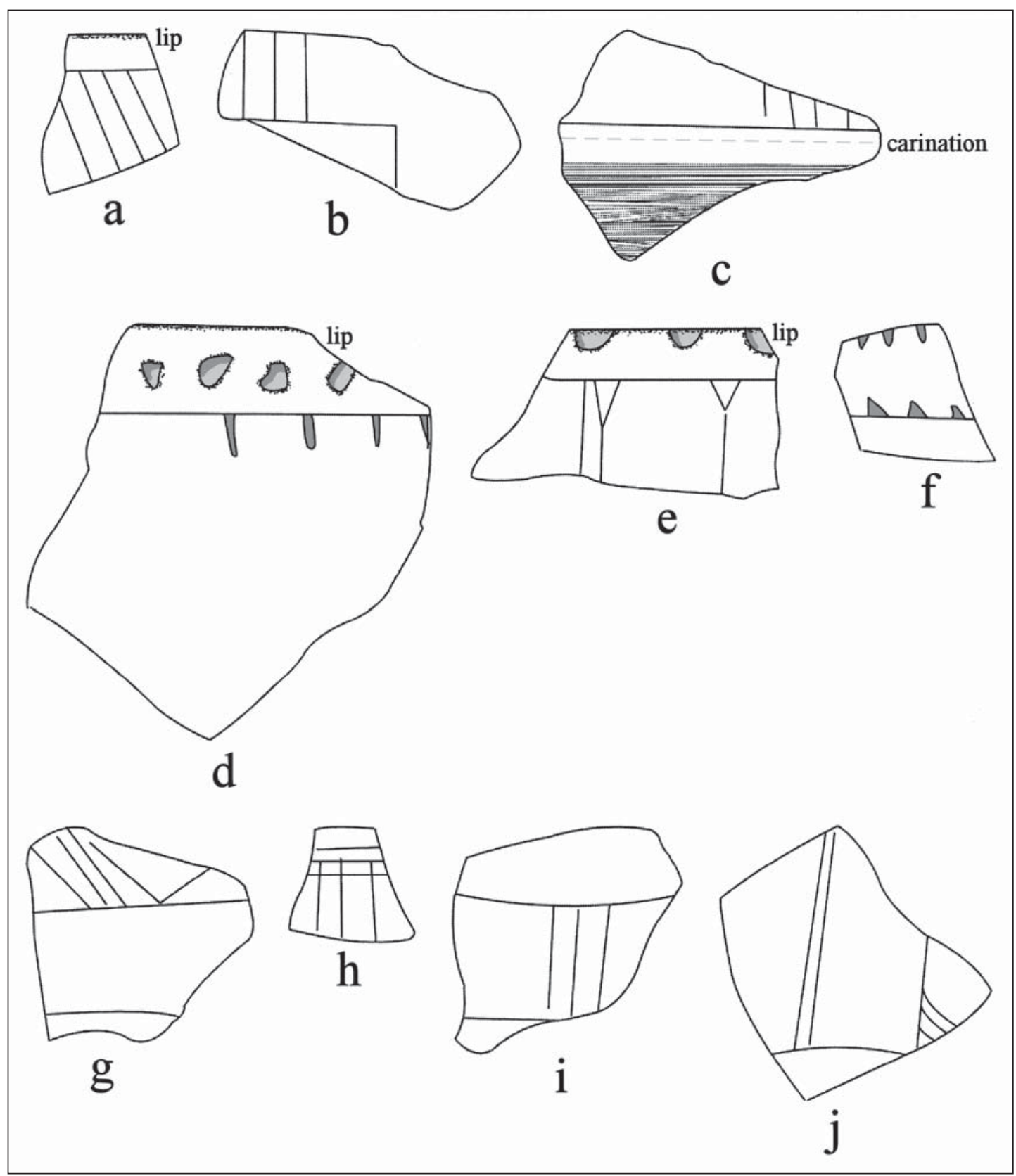

Figure 13. Selected engraved decorative elements on sherds from the Bowles Creek site.

Three sherds from ceramic elbow pipes are in the collections from the Bowles Creek site. One of the sherds is a Neches style grog-tempered elbow pipe bowl and heel sherd from Unit $3(70 \mathrm{~cm} \mathrm{bs})$ that has four rows of small circular punctations on the bowl and at least three rows of small circular punctations on the heel (Figure 14a). The second pipe sherd is a bowl rim from another Neches style grog-tempered elbow pipe from ST 10; this is about $20 \mathrm{~m}$ from Unit 3. It has at least five horizontal rows of small circular punctations on the upper part of the bowl (Figure 14b). A third pipe sherd is a plain grog-tempered elbow pipe bowl rim from Unit $1(0-45 \mathrm{~cm}$ bs).

The one historic artifact in the collection is a non-scalloped blue shell-edged rim from a whiteware plate. This type of whiteware plate was manufactured after ca. 1840 (Hunter and Miller 2009). 


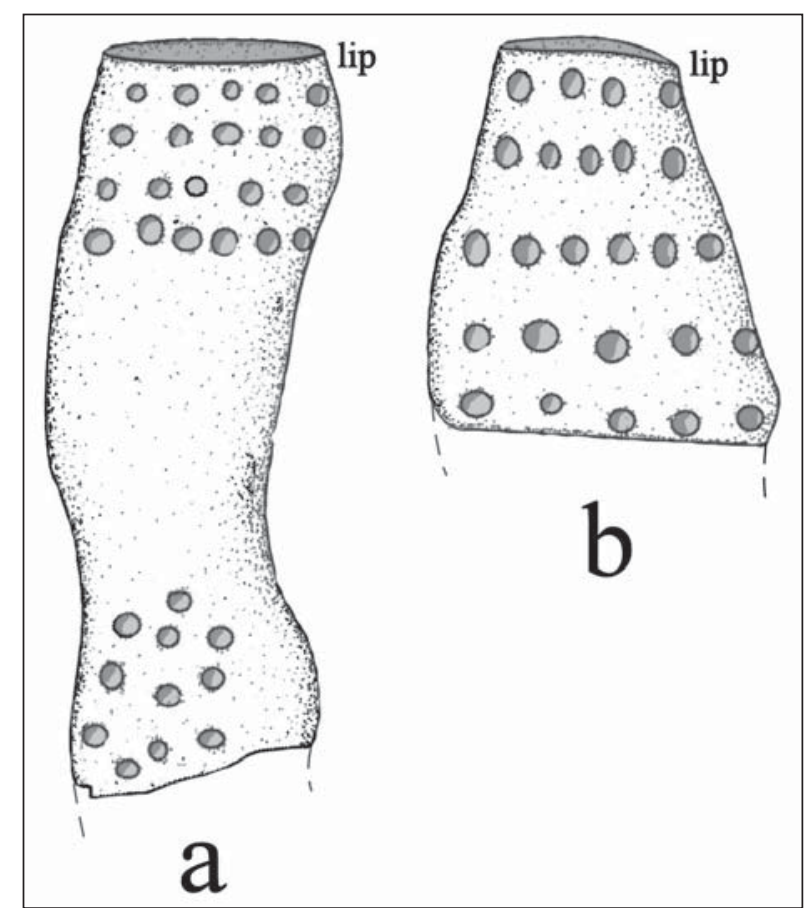

Figure 14. Decorative elements on Neches style elbow pipe sherd from the Bowles Creek site.

\section{Ceramic Assemblage Comparisons}

With the addition of the four new Cherokee County Historic Caddo sites with substantial plain and decorated sherd assemblages, there are now seven sites in Marceaux's (2011) Neche cluster in the middle Neches River basin. Selected attribute and assemblage-level comparisons of these sites are provided in Table 17.

Table 17. Ceramic sherd assemblage comparisons of Neche cluster sites.

\begin{tabular}{llllll}
\hline Site & $\%$ Grog & $\%$ Bone & P/DR & B/Pl & B/OWP** \\
\hline Group I & $98.1^{*}$ & 5.6 & 0.12 & 7.50 & 5.70 \\
$\begin{array}{l}41 \text { CE293 } \\
\text { Peach }\end{array}$ & 95.8 & 4.2 & 0.18 & 4.73 & 13.0 \\
$\quad \begin{array}{l}\text { Orchard } \\
\text { Golf Course }\end{array}$ & 97.1 & 2.9 & 0.30 & 3.08 & 9.25 \\
Group II & & & & & \\
41CE48 & 84.2 & 27.7 & 0.31 & 2.43 & 5.48 \\
Bowles & 91.2 & 9.2 & 0.34 & 2.55 & 11.3 \\
$\quad$ Creek & & & & & \\
41CE20 & $98.4^{*}$ & $14.3^{*}$ & 0.40 & 2.07 & 5.0 \\
Cornfield & 91.2 & 9.2 & 0.45 & 1.77 & 7.0 \\
\hline
\end{tabular}

$\mathrm{P} / \mathrm{DR}=$ plain to decorated sherd ratio; $\mathrm{B} / \mathrm{Pl}=$ brushed/plain sherd ratio; $\mathrm{B} / \mathrm{OWP}=$ brushed/other wet paste sherd ratio

*percentages will total to more than 100 percent because some sherds have more than one kind of temper **sherds with multiple decorative elements (i.e., brushed-incised or brushed-punctated, etc.) are counted as both brushed and as other wet paste sherds (OWP) 
There are several clear trends in these assemblages (see Table 17), which allows the seven assemblages to be sorted into two groups: (1) as the P/DR decreases from 0.45 (in Group II) to 0.12 (in Group I) from one assemblage to another, the proportion of sherds with bone temper decreases to only between 2.9-5.6 percent in the Group I sites. In the Group II sites, the proportion of bone temper ranges from 9.2-27.7 percent of the sherds in individual assemblages. Second, as the $\mathrm{P} / \mathrm{DR}$ ratio decreases, the $\mathrm{B} / \mathrm{Pl}$ ratio increases, such that the Group II sites - with P/DR ratios between 0.31-0.45-have B/Pl ratios between 1.77-2.55. Group I sherds have $\mathrm{B} / \mathrm{Pl}$ ratios between 3.08-7.50, with the highest $\mathrm{B} / \mathrm{Pl}$ ratio $(7.50)$ in the assemblage with the lowest $\mathrm{P} / \mathrm{DR}$, namely the Brooks Lindsey site (41CE293). These differences in the Neches cluster sites may have temporal differences, given the overall reduction in P/DR in ceramic sherd assemblages in Neches River basin Caddo sites after ca. A.D. 1200, with the Group II sites being slightly older than the Group I sites. These differences may also represent social-ethnic differences in ceramic practices and traditions that existed between the Caddo peoples that were living in Neches cluster sites after ca. A.D. 1650.

The identified ceramic types in the different Neches cluster sites form a consistent Allen phase set in both Group I and Group II assemblages, as they are dominated by sherds from Bullard Brushed and Patton Engraved vessels (Table 18). Also ubiquitous are sherds from Lindsey Grooved vessels. Poynor Engraved sherds are present in both Group I and II assemblages, as are sherds from King Engraved and La Rue Neck Banded vessels. Maydelle Incised, Killough Pinched, and Spradley Brushed-Incised sherds have been identified in only Group II sherd assemblages (Table 18).

Table 18. Identified ceramic types in the Neche cluster sites.

\begin{tabular}{|c|c|c|c|c|c|c|c|c|c|}
\hline Site & $\mathrm{PA}$ & $\mathrm{KE}$ & $\mathrm{PO}$ & LG & LNB & MI & $\mathrm{BB}$ & $\mathrm{KP}$ & SBI \\
\hline \multicolumn{10}{|l|}{ Group I } \\
\hline 41CE293 & & + & + & + & + & & + & & \\
\hline $\begin{array}{l}\text { Peach } \\
\text { Orchard }\end{array}$ & + & & & + & & & + & & \\
\hline Golf Course & + & & + & + & & & + & & \\
\hline \multicolumn{10}{|l|}{ Group II } \\
\hline 41CE48 & + & & & & + & & + & & \\
\hline $\begin{array}{c}\text { Bowles } \\
\text { Creek }\end{array}$ & + & & + & + & & & + & + & + \\
\hline 41CE20 & + & & + & & + & + & + & & \\
\hline Cornfield & + & + & & + & & & + & & \\
\hline
\end{tabular}

+=-presence; PA=Patton Engraved; KE=King Engraved; PO=Poynor Engraved; LG=Lindsey Grooved; LNB=La Rue Neck Banded; MI=Maydelle Incised; BB=Bullard Brushed; KP=Killough Pinched; SBI=Spradley Brushed-Incised

\section{Summary and Conclusions}

Recent archaeological investigations at four Historic Caddo sites in the Bowles Creek drainage in the Middle Neches River basin have obtained useful data on the character of such sites in the region. These sites appear to be single component habitation sites of the Allen phase that probably date to the late $17^{\text {th }}$ century; the Bowles Creek site has preserved animal remains and wood charcoal, as well as large pieces of burned clay in the archaeological deposits. At the present time, no associated European trade goods (i.e., glass beads, gunflints, iron gun parts, etc.) have been found at these four sites.

Ceramic vessel sherds are abundant at each of the four sites, and the sherds are from plain ware, utility ware, and fine ware vessels; the Bowles Creek site has Neches style pipe sherds. The ceramic vessels are predominantly from grog-tempered vessels, but sherds from bone-tempered vessels are relatively common at both the Bowles Creek and Cornfield sites. These assemblages are also dominated by sherds from utility 
ware jars with brushed decorative elements (Bullard Brushed), with low plain/decorated sherd ratios (0.45 and less), many brushed sherds relative to plain ware sherds, and considerable numbers of brushed sherds relative to other wet paste decorated sherds in the assemblages. Other than Bullard Brushed jar sherds, Lindsey Grooved sherds are present in the utility wares from each site, as are Patton Engraved fine ware sherds. Other identified ceramic types in these Bowles Creek ceramic assemblages are Poynor Engraved (especially at the Bowles Creek site), King Engraved, Killough Pinched, and Spradley Brushed-Incised.

Comparisons between the ceramics from these sites and other sites in this part of the Neches River basin with respect to the use of grog or bone temper in vessel manufacture and in various decorative attributes suggest that these Bowles Creek sites are part of the Neche cluster of Historic Allen phase sites defined by Marceaux (2011). These comparisons also suggest that the Neche cluster of sites can be divided into two groups of assemblages whose technological and stylistic differences may be the product of both temporal changes and social-ethnic diversity in ceramic practices and traditions that existed among Caddo peoples in this part of East Texas.

These four new Historic Caddo sites in Cherokee County warrant additional detailed archaeological investigations, including topographic mapping, systematic surface collections and shovel tests, remote sensing, and the judicious excavation of $1 \times 1$ or $1 \times 2 \mathrm{~m}$ units. Such work would be designed to establish the spatial extent of the archaeological deposits at each site, as well as determine the vertical and overall character of these deposits, along with assessing the likelihood that there are preserved habitation features (i.e., structures, pit features, and midden deposits) at the sites. The Bowles Creek site contains preserved plant and animal remains that should contribute important information on the subsistence character of the Caddo peoples living there, and these same remains can be employed to obtain AMS radiocarbon dates on the archaeological deposits.

It is also important that additional archaeological survey investigations be continued in this part of the Bowles Creek valley. These survey investigations will likely identify other Historic Caddo settlements that are part of a community of Caddo peoples of the Neche cluster.

\section{Acknowledgments}

Thanks to Lance Trask and Sandy Hannum for preparing several of the figures presented in this article. Photographs in this article were provided by Kevin Stingley. Thanks also to the landowner for permission to document the four sites and to study the collections obtained from them.

\section{References Cited}

Cole, N. M.

1975 Early Historic Caddoan Mortuary Practices in the Upper Neches Drainage, East Texas. Master's thesis, Department of Anthropology, The University of Texas at Austin.

Corbin, J. E.

1996 Spanish-Caddoan Interaction in Eastern Texas. Journal of Northeast Texas Archaeology 7:20-26.

Corbin, J. E., H. A. Brown, M. G. Canavan, and S. Toups

1990 Mission Dolores de los Ais (41SA25): San Augustine County, Texas, Archeological Investigations. Stephen F. Austin State University, Nacogdoches

Fields, R. C.

1995 Analysis of Native-Made Ceramics. In The Deshazo Site, Nacogdoches County. Texas, Volume 2: Artifacts of Native Manufacture, edited by D. A. Story, pp. 173-232. Studies in Archeology 21. Texas Archeological Research Laboratory The University of Texas at Austin. 
2008 The Pine Tree Mound Site and the Entrada of the Hernando De Soto Expedition of 1542. Journal of Northeast Texas Archaeology 28:1-8.

Gilmore, K.

1983 Caddoan Interaction in the Neches Valley, Texas. Reprints in Anthropology No. 27. J\&L Reprint Company, Lincoln.

1986 French-Indian Interaction at an Early Eighteenth Century Post: The Roseborough Lake Site, Bowie County, Texas. Contributions in Archaeology 3. Institute of Applied Sciences, North Texas State University, Denton.

Hunter, R. and G. L. Miller

2009 Suitable for Framing: Decorated Shell-Edge Earthenware. Early American Life, August 2009, pp. 8-19.

Jackson, A. T.

1933 Some Pipes of East Texas. Bulletin of the Texas Archeological and Paleontological Society 5:69-86.

1936 A Perpetual Fire Site. Bulletin of the Texas Archeological and Paleontological Society 8:134-174.

Jackson, M. K., T. Middlebrook, G. Avery, H. Shafer, and B. Meissner

2012 Trade and Cultural Interaction along El Camino Real de los Tejas During the Spanish Colonial and Republic Periods in Nacogdoches County, Texas. 2 Vols. Nine Flags Museum, Nacogdoches.

Marceaux, P. S.

2011 The Archaeology and Ethnohistory of the Hasinai Caddo: Material Culture and the Course of European Contact. Ph.D. dissertation, Department of Anthropology, The University of Texas at Austin.

Marceaux, P. S. and T. K. Perttula

2010 Negotiating Borders: The Southern Caddo and Their Relationships with Colonial Governments in East Texas. In American Indians and the Market Economy, 1775-1850, edited by L. Greene and M. R. Plane, pp. 80-97. University of Alabama Press, Tuscaloosa.

Marceaux, P. S. and M. F. Wade

2014 Missions Untenable: Experiences of the Hasinai Caddo and the Spanish in East Texas. In Indigenous Landscapes and Spanish Missions: New Perspectives from Archaeology and Ethnohistory, edited by L. M. Panich and T. D. Schneider, pp. 57-75. University of Arizona Press, Tucson.

Parsons, M. L., J. Bruseth, J. Bagur, and C. McCrocklin

2002a Finding Sha'chahdinnih (Timber Hill): The Last Village of the Kadohadacho in the Caddo Homeland. Plains Anthropologist 47(182):231-249.

Parsons, M. L., J. E. Bruseth, J. Bagur, S. E. Goldborer, and C. McCrocklin

2002b Finding Sha'chahdinnih (Timber Hill): The Last Village of the Kadohadacho in the Caddo Homeland. Archeological Reports Series No. 3. Texas Historical Commission, Austin.

Perttula, T. K.

1991 European Contact and its Effects on Aboriginal Caddoan Populations between A.D. 1520 and A.D. 1680. In Columbian Consequences, Vol. 3, The Spanish Borderlands in Pan-American Perspective, edited by D. H. Thomas, pp. 501-518. Smithsonian Institution Press, Washington, D.C.

1992 "The Caddo Nation": Archaeological and Ethnohistoric Perspectives. University of Texas Press, Austin.

1993 Kee-Oh-Na-Wah'-Wah: The Effects of European Contact on the Caddoan Indians of Texas, Louisiana, Arkansas and Oklahoma. In Ethnohistory and Archaeology: Approaches to Postcontact Change in the Americas, edited by J. D. Rogers and S. M. Wilson, pp. 89-109. Plenum Press, New York.

2001 "The Great Kingdom of the Tejas": The Life and Times of Caddo Peoples in Texas between ca. 15301859. Bulletin of the Texas Archeological Society 72:73-89. 
2002 Social Changes among the Caddo Indians in the Sixteenth and Seventeenth Centuries. In The Transformation of the Southeastern Indians, 1540-1760, edited by R. Ethridge and C. Hudson, pp. 249-269. University Press of Mississippi, Jackson.

2007a Upper Neches River Basin Caddo Ceramics, an Attempt at an Updated Seriation and a Context for Understanding Frankston to Allen Phase Ceramic Stylistic and Technological Change. Journal of Northeast Texas Archaeology 26:154-158.

2007b Kinsloe Focus Artifact Assemblages and Nadaco Caddo. Journal of Northeast Texas Archaeology 26:116119.

2008 Trends and Varieties in Late Caddo and Historic Caddo Fine Ware Pottery Types in the Upper Neches River Basin. Journal of Northeast Texas Archaeology 28:51-55.

2012 The Archaeology of the Caddo in Southwest Arkansas, Northwest Louisiana, Eastern Oklahoma, and East Texas: An Introduction to the Volume. In The Archaeology of the Caddo, edited by T. K. Perttula and C. P. Walker, pp. 1-25. University of Nebraska Press, Lincoln.

Story, D. A. (editor)

1982 The Deshazo Site, Nacogdoches County, Texas, Vol. 1: The Site, Its Setting, Investigations, Cultural Features, Artifacts of Non-Native Manufacture, and Subsistence Remains. Texas Antiquities Permit Series No. 7. Texas Antiquities Committee, Austin.

1995 The Deshazo Site, Nacogdoches County, Texas, Vol. 2: Artifacts of Native Manufacture. Studies in Archeology 21. Texas Archeological Research Laboratory, The University of Texas at Austin.

Story, D. A. and D. G. Creel

1982 The Cultural Setting. In The Deshazo Site, Nacogdoches County, Texas, Vol. 1, edited by D. A. Story, pp. 20-34. Texas Antiquities Permit Series No. 7. Texas Antiquities Committee, Austin. 